\title{
Good corporate governance practices and voluntary disclosure in companies listed in the Indonesia Sharia Stock Index (ISSI)
}

\author{
Avininda Dewi Nindiasari \\ Universitas 'Aisyiyah Yogyakarta, Yogyakarta, Indonesia \\ ${ }^{*}$ Corresponding author: avinindadn@unisayogya.ac.id
}

\begin{abstract}
Objectives: This study aims to determine the effect of the size of the board of commissioners, the proportion of independent commissioners, family ownership, and audit quality on the level of voluntary disclosure of the company.

Design/methodology/approach: An empirical study of 50 companies listed in the Indonesia Sharia Stock Index (ISSI) is conducted using the 2015-2016 annual report. The type of data used is secondary data. The analytical method used in this study is multiple linear regression analysis with SPSS 21.
\end{abstract}

Findings: The results of statistical tests indicate that the size of the board of commissioners and audit quality have a positive and significant effect on the level of voluntary disclosure, while the proportion of independent commissioners and family ownership has no significant effect on the level of voluntary disclosure.

Implications: The main implications of the results of this study are the size of the board of commissioner and the audit quality. The size of the board of commissioners has a strong relationship to the level of voluntary disclosure. There is a relationship between the number of the board of commissioners and the national laws that have an impact on monitoring the transparency process and the effectiveness of communication within the company. For audit quality, companies that use Big Four audit firms have an effect on the level of voluntary disclosure since their financial reporting will result in better audit quality with a high level of independence. The results of this study also support that agency theory is able to partially explain the phenomenon of the relationship between corporate governance practices and the level of voluntary disclosure in companies listed in ISSI.

Originality/Value: This research is one of the studies that draw a relationship between the size of the board of commissioners and audit quality on the level of voluntary disclosure of companies in Indonesia. This finding provides confidence that the size of the board of commissioners and audit quality complement each other to improve the quality of voluntary disclosure.

Keywords: Voluntary Disclosure, Corporate Governance Practices, ISSI

Cite this article:

Nindiasari, A. D. (2021). Good corporate governance practices and voluntary disclosure in companies listed in the Indonesia Sharia Stock Index (ISSI). Asian Journal of Islamic Management, 3 (1), 45-55. https:/ /doi.org/10.1108/AJIM.vol3.iss1.art5
Article history

Received, 4 May 2021 Revised 1, 9 May 2021 Revised 2, 20 May 2021 Accepted, 28 May 2021

\section{Introduction}

The specific purpose of financial reporting in the International Financial Reporting Standards (IFRS) is to provide information about the company that can be used by outside parties and potential investors, lenders, and other parties who need to make decisions about the resources of the company (Al-shammari, 2013). Meanwhile, companies use it to communicate existing 
information to stakeholders to make the right economic decisions (Ikatan Akuntan Indonesia, 2012). Financial reporting disclosures submitted to the Financial Services Authority (OJK) can be in the form of financial reports or annual reports. These disclosures can be categorized into two, which are mandatory disclosure as stipulated in the Decree of the Chairman of Bapepam No.Kep431/BL/2012 (Bapepam, 2012) and voluntary disclosure that is additional information beyond the mandatory one.

Voluntary disclosure is getting more concerns because it has a high demand and one of the ways to increase the credibility of financial reporting, assist investors in understanding the company's business strategy, has a contribution to equity value, market liquidity, cost of capital, and overall to reduce agency problems between managers and external investors (Akhtaruddin and Haron, 2010). The policy of the extent of voluntary disclosure will differ from one company to another. This is because the extent of voluntary disclosure in a company is influenced by attitudes in social, economic, and behavioral factors, especially corporate culture. There are several companies that do not carry out social activities because they will be reported voluntarily which will later interfere with information about the success of financial statements (Syahierah and Larasati, 2019).

The amount of information disclosed as to the extent of voluntary disclosure is related to company transparency and accountability. Transparency and disclosure in the company's annual report are included in the corporate governance pillars (Shehata, 2014). The implementation of Good Corporate Governance improves management supervision to encourage corporate decision making, prevent opportunistic actions that are not in accordance with the company's interests and reduce information asymmetry between management and company stakeholders (Pernamasari, 2018). The separation of ownership and control in a public company may create an agency conflict between shareholders (principals) and management (agents). Management who runs a business knows more about the company's business information than shareholders, thus management can defend their interests and take over the principal or for companies that have concentrated ownership, management will take over minority ownership (Ratnasari and Adhariani, 2019).

Many studies on the relationship between good corporate governance and voluntary disclosure have been carried out. Previous research has found evidence that good corporate governance practices positively increase corporate transparency through increasing levels of voluntary disclosure such as the research of Haniffa and Cooke (2000), Chen and Jaggi (2000), Ho and Wong (2001), Rouf (2011), Allegrini \& Greco (2011), Nugraheni and Anuar (2014) and Agyeimensah (2018). Moreover, the previous researches found that the size of the board of commissioners has a positive effect (Allegrini \& Greco, 2011), the proportion of independent commissioners has a positive effect (Chen and Jaggi, 2000), family ownership has a negative effect (Ho \& Shun Wong, 2001) and audit quality has a positive effect (Agyei-mensah, 2018; Jaffar et al., 2013).

The results of the research above must be interpreted with caution and cannot be interpreted the same for every country used in the study. Each country has different regulations and mechanisms for implementing corporate governance, especially on the board structure. There are two types of board structures, namely the one-tier board system and the two-tier board system. Most of the results of the research above were carried out in countries that adopted one-tier board structure, while Indonesia implemented two-tier board system. Therefore, the relationship between corporate governance practices and the level of voluntary disclosure implemented in countries that adopt a two-tier board structure has not been widely discussed.

The uniqueness of the corporate governance framework in Indonesia provides an opportunity to expand previous research on the relationship between corporate governance practices and the extent of voluntary disclosure. The relationship between the two variables is estimated to have a strong relationship because all boards are not executive members, they can perform their duties more effectively and require more voluntary disclosure to investors (Jaffar et al., 2013). In addition, Indonesia is one of the countries where the majority of company ownership are controlled by families (PricewaterhouseCoopers, 2014). Concentrated family ownership structure will affect several things, such as the lack of agency problems and agency costs, corporate 
performance, and corporate policy-making patterns. This makes family ownership become one of the things that is closely related to the extent of the company's voluntary disclosure.

Based on the above explanations, it is important to conduct research on the relationship between corporate governance practices and voluntary disclosure in Indonesia. Using the variables above, the researcher wants to show the relationship between corporate governance practices such as the size of the board of commissioners, the proportion of independent commissioners, family ownership, and audit quality on voluntary disclosure in Indonesia. This research is expected to contribute to the development of the literature concept on corporate governance practices on voluntary disclosure for public companies in Indonesia. This study uses company data listed in the Indonesia Sharia Stock Index (ISSI). It is believed that the companies listed in this index have a high concern for voluntary disclosure because the conformity of operational activities with sharia principles encourages companies to make disclosures more to the public where the majority in Indonesia is Muslim.

\section{Literature Review and Hypotheses Development}

\section{Voluntary Disclosure}

Voluntary disclosure is the disclosure of information beyond the mandatory disclosure or disclosure of information that is not regulated in the Decree of the Chairman of Bapepam No.Kep431/BL/2012. According to Suwardjono (2011), voluntary disclosure is a disclosure made by the company beyond what is required by accounting standards or regulatory bodies. Voluntary disclosure is provided voluntarily by the company to the users of the company's annual report. Another definition states that voluntary disclosure is the freedom of company management to provide accounting information and other relevant information for decision making required by users of the annual report, including disclosures recommended by authorized parties or bodies (Shehata, 2014). The information contained in the voluntary disclosure is classified into three types, namely strategic information which contains general company information, financial information, and non-financial information $(\mathrm{Qu}$, Leung, and Cooper, 2013).

\section{Agency Theory}

Agency theory explains the relationship between shareholders (principal) and management (agent). The relationship is a contractual relationship in which the agent is required to perform several services on behalf of the principal by involving the delegation of decision-making authority to the agent (Barako, 2007). In companies with simple capital and funding structures, the contractual relationship does not cause agency problems within the company. However, in companies that have traded shares to the public, there will automatically be a separation between shareholders and management. This is what gives rise to agency conflicts between shareholders and management, where management has more information related to the condition of the company than shareholders. There are two information asymmetries formed, which are adverse selection related to errors in decision making due to lack of information and moral hazard related to actions to fulfill their own interests due to opportunities from information asymmetry.

The existence of good corporate governance practices can minimize agency conflicts between shareholders and management through disclosure and transparency of corporate governance mechanisms. In this study, voluntary disclosure can be used to apply agency theory in the sense that management who has more and better access to company information can make reasonable and reliable communications to the market in order to optimize the value of the company (Barako et al., 2006)

\section{Size of Board of Commissioners}

The Board of Commissioners is an organ of the Public Company with the role of conducting general and/or specific supervision in accordance with the regulations of association and providing 
advice to the Board of Directors (Otoritas Jasa Keuangan, 2014). The board of commissioners has a role as management supervisor in managing the company and creating accountability. The optimal size of the board is an important issue for companies. The number of commissioners will affect the possibility of information asymmetry (Chen and Jaggi, 2000). One of the contributions of the board of commissioners is to reduce conflicts between agents and principals. The large number of commissioners will affect the need for disclosure of information, this is based on the experience and expertise of the board members. Companies with a larger board size are likely to disclose more information voluntarily compared to companies with a small board size (Milad \& Bicer, 2020). Thus, it is possible that the size of the board of commissioners has a positive influence on voluntary disclosure (Allegrini \& Greco, 2011; Krismiaji, 2020; Milad \& Bicer, 2020).

H1: Size of Board of Commissioners positively influences voluntary disclosure

\section{Proportion of Independent Commissioners}

According to the regulation, the Independent Commissioner is an independent member of the Board of Commissioners, supervision by professional parties will be more guaranteed and independent commissioners come from outside the Public Company and fulfill the requirements as Independent Commissioner (Otoritas Jasa Keuangan, 2014). Independent commissioners who are neutral to all directors' policies have an important role, especially to reduce agency conflicts (Surya \& Yustiavandana, 2006). Agency conflicts that can arise are related to the disclosure of more information in the annual report, namely the low transparency. The independent board of commissioners has two functions, which include service and control functions. The service function of the independent board of commissioners can provide management consultation and advice, while the control function is to control the opportunistic behavior of management to align the interests of shareholders and managers. The regulations stipulated in POJK No. $33 /$ POJK.04/2014 require the number of independent commissioners to be at least $30 \%$ of the total number of commissioners (Otoritas Jasa Keuangan, 2014). The existence of independent commissioners can provide advice and input to management because of their experience, expertise and network. Thus, it is possible that the proportion of independent commissioners has a positive influence on voluntary disclosure (Nasih et al., 2019).

H2: Proportion of Independent Commissioners positively influences voluntary disclosure

\section{Family Ownership}

Several previous studies have stated that the ownership structure factor has an influence on the level of company disclosure, especially on the family ownership structure. In agency theory, a company that is not concentrated will disclose more information to reduce agency costs and information asymmetry. It is in contrast to companies with a concentrated ownership structure. Family-controlled companies tend to have the right to control the company by maximizing their own interests while ignoring the benefits of others. Therefore, family-controlled companies do not need further information because they can get information from the company easily (Haddad et al., 2015). Therefore, it is possible for companies controlled by family to have greater company information, hence it is possible that it will affect the extent of information disclosure to outside parties (Ho \& Shun Wong, 2001). Thus, it is also possible that family ownership has a negative effect on voluntary disclosure (Haddad et al., 2015; Ho \& Shun Wong, 2001)

H3: Family Ownership negatively influences voluntary disclosure

\section{Audit Quality}

According to regulation concerning the Implementation of Good Corporate Governance in Company PMK No. 88/PMK.06/2015, the company is required to conduct an audit by an external auditor appointed by the Annual General Meeting of Shareholders, the candidates proposed by the Board of Commissioners and the external auditor must be free from the influence of the Board of 
Commissioners, Board of Directors and Shareholders (Pemerintah Republik Indonesia, 2017). The main role of external auditors is to monitor and ensure that management complies with state laws and regulations (Jaffar et al., 2013). The quality of the external auditors themselves can help reduce agency problems. The higher the audit quality, it will increase the credibility of the accounting information disclosed by the company, finally it will reduce the bias produced by management actions. Audit quality is influenced by the size of the audit firm, where the larger the audit firm size, the higher the audit quality in finding material errors and irregularities. Hence, it will affect the quality of disclosure.(Jaffar et al., 2013). The selection of an external auditor is part of the company's disclosure strategy. Providing advice will give signal about the company's decision to provide high quality disclosures. Based on the explanation above, it is possible that audit quality has a positive influence on voluntary disclosure (Agyei-mensah, 2018; Jaffar et al., 2013).

H4: Audit Quality positively influences voluntary disclosure

\section{Methods}

This study uses secondary data on companies listed in the Indonesia Sharia Stock Index (ISSI). Determination of the sample was obtained using simple random sampling through the SPSS application, in order to determine 50 companies randomly, which had previously been selected with the criteria (1) Companies were not delisted from the Indonesia Sharia Stock Index during the research period of 2015-2016 and (2) Companies with incomplete data excluded from the study sample.

Therefore, the sample size in this study is 100 samples. The source of the data used is in the form of secondary data obtained through the Indonesia Stock Exchange website and the company's official website. To determine the variable of family ownership itself, the researchers used other sources as well, such as company prospectuses and internet sources. The determination of the company being included in a family company is performed by (1) Identifying the controlling surname by searching for names, whether there is repetition of the surname in the names of shareholders or not, boards of directors and boards of commissioners in the annual report and (2) If the company is legally owned indirectly, traced using a company prospectus through history of ownership and checking potential surnames through various internet sources that may be based on name relationships (Jaffar et al., 2013).

\section{Variable Measurement}

The level of voluntary disclosure in this study uses the modified item in the Nugraheni and Anuar (2014) a total of 30 items as well as disclosure items in the study Akhtaruddin and Haron (2010) a total of 64 items. Through adjustments between the items in the two previous studies and according to the Decree of the Chairman of Bapepam No.Kep-431/BL/2012, the voluntary disclosure items used were 35 items of voluntary disclosure. Furthermore, the level of voluntary disclosure is measured based on the disclosure score index. In line with previous research, the type of disclosure score index uses an unweighted disclosure approach, the company is given a value of "1" for items disclosed in the annual report and " 0 " if not disclosed. The voluntary disclosure index (VDX) is then calculated for each sampled company as the ratio of the total disclosure score to the maximum possible disclosure by the company. The disclosure index for each company is then expressed as a percentage (Akhtaruddin \& Haron, 2010; Nugraheni \& Anuar, 2014; Rouf, 2011)

Voluntary Disclosure $=\frac{\text { Actual Disclosure }}{\text { Total Posibble Disclosure (35) }} \times 100 \%$

According to previous researches of Chen and Jaggi (2000), Ho and Wong (2001) and Jaffar et al., (2013), This study uses 4 independent variables, namely the size of the board of commissioners, the proportion of independent commissioners, family ownership and audit quality. The size of the board of commissioners uses a proxy for the total number of board members in the company. The size of the board of commissioners is measured by the total number of 
commissioners in the company (Allegrini \& Greco, 2011). The proportion of independent commissioners is measured by the number of independent commissioners divided by the total number of the Board of Commissioners. Family ownership is measured on a dichotomous basis, which is given a value of " 1 " if there is family ownership and " 0 " otherwise (Ho \& Shun Wong, 2001).

Audit quality is measured based on whether the company is audited by an audit firm that is included in the Big Four category or not. A value of " 1 " is given if the company is audited by a Big Four Audit Firm and a value of " 0 " otherwise. To determine the quality of audits in Indonesia, audit firms that have affiliations with the Big Four International Audit Firms such as Purwantono, Suherman and Surya Audit Firms (Affiliated with Ernst \& Young), Osman Bing Satrio Audit Firms (Affiliated with Deloitte Touche Tohmatsu), Audit Firms Siddharta and Widjaja (Affiliate with KMG) and Audit Firm Tanudiredja, Wibisana and Partner (Affiliate with Price Waterhouse Coopers)(Jaffar et al., 2013). The complete measurement of each variable can be seen in table 1.

Tabel 1. Independent Variable Measurement

\begin{tabular}{|c|c|c|c|}
\hline Variable & Measurement & Data Type & $\begin{array}{l}\text { Source of } \\
\text { Information }\end{array}$ \\
\hline $\begin{array}{l}\text { The size of board } \\
\text { of commissioners }\end{array}$ & $\begin{array}{l}\text { The total number of commissioners in the } \\
\text { company (Allegrini \& Greco, 2011; Nugraheni } \\
\text { \& Anuar, 2014; Rouf, 2011) }\end{array}$ & Continuous & Annual Report \\
\hline $\begin{array}{l}\text { The proportion of } \\
\text { independent } \\
\text { commissioners }\end{array}$ & $\begin{array}{l}\text { Percentage of independent board of } \\
\text { commissioners within the board of } \\
\text { commissioners (Chen \& Jaggi, 2000) }\end{array}$ & Continuous & Annual Report \\
\hline Family Ownership & $\begin{array}{l}\text { Value of " } 1 \text { " if there is family ownership and } \\
\text { "0" otherwise (Ho \& Shun Wong, 2001). }\end{array}$ & Categorical & $\begin{array}{l}\text { Annual Report, } \\
\text { Company } \\
\text { Prospectus and } \\
\text { internet. }\end{array}$ \\
\hline Audit Quality & $\begin{array}{l}\text { Value of " } 1 \text { " if audited by Big Four affiliated } \\
\text { audit firm and " } 0 \text { " otherwise (Jaffar et al., 2013) }\end{array}$ & Category & Annual Report \\
\hline
\end{tabular}

\section{Results}

\section{Descriptive Statistics}

Table 2 presents the descriptive statistical results of the independent variables. From table 2, the variable size of the board of commissioners ranges from 2 to 11 people and the average size is 5 people. The variable proportion of independent commissioners ranges from $16.67 \%$ to $60 \%$ with an average value of $38.33 \%$. For the categorical variable of family ownership, it shows that the majority of companies used in this study that have family ownership (value 1) are $46 \%$, while companies that do not have family ownership (value 0 ) are $54 \%$. This shows that, of the 50 companies, there are 23 family-owned companies. Furthermore, the categorical variable of audit quality shows that the majority of the companies used in this study were audited by audit firms affiliated with the Big Four (score 1) are 28 companies or 56\%, while the companies audited by audit firms unaffiliated with the Big Four (score 0 ) are 22 companies or $44 \%$ of the total companies.

Table 3 shows the descriptive statistical results of the dependent variable on the level of voluntary disclosure. Table 3 shows the average value of the voluntary disclosure rate index in $2015-2016$ is 0.4822 or $48.22 \%$ with a standard deviation of $13.47 \%$. The minimum value of the disclosure level is $23 \%$ and the maximum value is $77 \%$. 
Table 2. Independent Variable Descriptive Statistical Analysis

Panel A. Continuous Variable

\begin{tabular}{llrrrr}
\hline \multicolumn{1}{c}{ Variable } & n & \multicolumn{1}{c}{ Min } & \multicolumn{1}{c}{ Max } & \multicolumn{1}{c}{ Mean } & \multicolumn{1}{c}{ SD } \\
\hline Size of Board of Commissioners (People) & 100 & 2 & 11 & 5,02 & 1,803 \\
Proportion of Independent Commissioners (\%) & 100 & 16,67 & 60 & 38,34 & 76,76 \\
\hline
\end{tabular}

Panel B. Categorical Variable

\begin{tabular}{llc}
\hline \multicolumn{1}{c}{ Variable } & \multicolumn{1}{c}{ Measurements } & Percentage \\
\hline Family Ownership & 1: If there is family ownership & 46 \\
& 0: If there is no family ownership & 54 \\
Audit Quality & 1: Audited by Big Four-affiliated audit firm & 56 \\
& 0: Audited by non Big Four--affiliated audit firm & 44
\end{tabular}

Source: Processed Secondary Data, 2021

Table 3. Descriptive Statistical Analysis of Dependent Variables

\begin{tabular}{lccccc}
\hline \multicolumn{1}{c}{ Variable } & n & Min & Max & Mean & SD \\
\hline Level of Voluntary Disclosure (\%) & 100 & 23 & 77 & 48,22 & 13,47 \\
\hline Source: Processed Secondary Data, 2021 & & & & &
\end{tabular}

\section{Discussion}

Table 4 shows that the Adjusted R-Square value is 0.248 . This shows that the size of the board of commissioners, the proportion of independent commissioners, family ownership and audit quality affect the company's voluntary disclosure level only by $24.8 \%$, while the remaining $75.2 \%$ is explained by other factors.

The following will discuss the relationship between the independent and dependent variables. First, based on the results presented in Table 4, there is a positive relationship between the size of the board of commissioners and the level of voluntary disclosure (0.033) and it is significant at the significance level of $5 \%(\mathrm{p}=0.000)$. These results are in accordance with the research of Krismiaji and Kusumadewi (2019) and Milad \& Bicer (2020) who found that the larger the size of the board of commissioners will increase the company's voluntary disclosure and vice versa. These results provide empirical evidence that a large number of commissioners can reduce the possibility of information asymmetry, because they can contribute more to reducing distributional conflicts between agents and principals. With more boards of commissioners, the experience and expertise of the board of commissioners will also increase, thus the need for information disclosure will also increase. This explanation is also supported by the compliance of companies registered in ISSI related to the number of commissioners in the company in accordance with POJK No. 33/POJK.04/2014, which is a minimum of two people (Otoritas Jasa Keuangan, 2014).

Second, there is a positive relationship between the proportion of independent commissioners and the level of voluntary disclosure (0.108) but it is not significant at the significance level of $5 \%(\mathrm{p}=0.487)$. These results indicate that the proportion of independent commissioners does not affect the level of voluntary disclosure of the company. This is in line with the research results of (Ho \& Shun Wong, 2001), Rouf (2011) and Harventy (2020). This result is possible because the agency theory used to link the variable proportion of independent commissioners and the level of voluntary disclosure is weak. This statement is supported by Fatmawati et al., (2018) which implied that for both variables, it is better to use signalling theory for interested company to convey information that can increase company credibility although the information is not required to give a positive signal of the company. Furthermore, independent commissioners prefer to comply and make mandatory disclosures in accordance with regulations. This is allegedly because their position is more to meet the regulations of POJK No. 
33/POJK.04/2014 (must have at least 30\% of the total number of commissioners, the average result of the proportion of independent commissioners in this study is $38 \%$ ).

Third, there is a negative relationship between family ownership and the level of voluntary disclosure (-0.019) but it is not significant at the significance level of $5 \%(p=0.430)$. These results also indicate that family ownership does not affect the company's level of voluntary disclosure. This results can be explained due to the family firms are less involved in opportunistic behavior (voluntary disclosure). They only focus on mandatory disclosure in accordance with the Decree of the Chairman of Bapepam No.Kep-431/BL/2012, allegedly this is conducted to maintain their position and want to pass the company on to the next generation (be more careful with disclosing information)

Finally, for audit quality, there is a positive relationship between audit quality and the level of voluntary disclosure (0.056) and it is significant at the significance level of $5 \%(p=0.027)$. These results are in accordance with the research of Jaffar et al., (2013) who found that audit quality was influenced by the size of the audit firm, where the larger the audit firm size, the higher the audit quality in finding material errors and irregularities. Hence, this will affect the quality of disclosure. Not only that, this also indicates that auditors who concern about their reputation will encourage their clients to provide more comprehensive disclosures.

Table 4. The results of the relationship between the independent variables and the level of voluntary disclosure

\begin{tabular}{lcccc}
\hline \multicolumn{1}{c}{ Variable } & Prediction & $\begin{array}{c}\text { Regression } \\
\text { Coefficient }\end{array}$ & Significance & Conclusion \\
\hline Constant & & 0,252 & & \\
Size of Board of Commissioners & + & 0,033 & $0,000^{* *}$ & Significant \\
Proportion of Independent commissioners & + & 0,108 & 0,487 & Not Significant \\
Family Ownership & - & $-0,019$ & 0,430 & Not Significant \\
Audit Quality & + & 0,056 & 0,027 & Significant \\
\hline Model Summary: & & & \\
$\mathrm{n}=100 ;$ Adjusted R-Square $=0,248 ;$ R-Square $=0,279 ;$ Uji F (p-value) $=0,000$ & & \\
Regression Model = 0,000*** & & & \\
\hline
\end{tabular}

Source: Processed Secondary Data, 2021

\section{Implication}

The main issue raised in this research is the influence of corporate governance practices on the level of voluntary disclosure of companies in Indonesia. The existence of differences in corporate governance practices between the two-tier board system and the one-tier board system will affect the management and decisions of each company. Each country has different regulations and mechanisms for implementing corporate governance, especially on the board structure adopted by each country. All decisions must be interpreted with caution and cannot be interpreted the same for every country.

The corporate governance factors used in this study are the size of the board of commissioners, the proportion of independent commissioners, family ownership, and audit quality. This study predicts that the size of the board of commissioners will greatly affect the level of voluntary disclosure. This is because members of the board of commissioners are non-executive members (cannot perform executive duties in an organization). The test results in this study indicate that the size of the board of commissioners has a strong relationship to the level of voluntary disclosure. Based on these results, it can be said that although members of the board of commissioners are not allowed to hold executive positions in a company, this does not prevent them from being involved in matters related to the company's operations. This is in accordance with the roles of the board of commissioners, which are supervising and providing advice to the 
board of directors in running the company. However, the results of this study affect the proportion of independent commissioners and family ownership. 44\% of the members of the board of commissioners are close family members or have business relationships with major shareholders or the company. This indicates that regulators in Indonesia need to consider and review the prevailing laws and regulations to ensure that the members of the board of commissioners are truly independent, thus, they can monitor the performance of executive managers effectively and objectively. Furthermore, audit quality is predicted to affect the level of voluntary disclosure because the more affiliations with the Big Four audit firm, the better audit quality will be. Additionally, the bigger the audit firm, the higher the level of independence.

\section{Conclusion}

This study is an empirical study that analyzes the effect of the size of the board of commissioners, the proportion of independent commissioners, audit quality and family ownership with voluntary disclosure in companies listed in the Indonesia Sharia Stock Index (ISSI) in 2015-2016 using agency theory as a theoretical framework. A total of 50 companies were included in this study and voluntary disclosure was measured using an unweighted disclosure approach.

The conclusion of the answer to the problem formulation in this study is that the size of the board has a significant effect on voluntary disclosure, the proportion of independent commissioners has no significant effect on voluntary disclosure, audit quality has a significant positive effect on voluntary disclosure and family ownership has no significant effect on voluntary disclosure. It can be concluded that the size of the board of commissioners in accordance with POJK No. 33/POJK.04/2014 helps in increasing transparency and provides advice on strategic options to improve the company's image. The authors also conclude that audit quality can help transparency, but has not shown any effect of the proportion of independent commissioners and family ownership on the company's voluntary disclosures.

This study has several limitations. First, future research needs to further investigate the relationship between the proportion of independent commissioners and the level of voluntary disclosure. Due to the uniqueness of using the two-tier board system in Indonesia, this research needs to be re-conducted as a step to improve the legislation related to the right proportion and independence of independent board of commissioners. Second, future research could further examine the effect of family ownership on the level of voluntary disclosure. As a country with large family ownership, this is unique in how the role of family control over the level of voluntary disclosure. Third, the level of voluntary disclosure is measured using an unweighted disclosure approach, not yet measuring the quality of the information content disclosed. It can be said that the measurement of the disclosure index based on the quality of information will provide a stronger relationship between corporate governance and voluntary disclosure. Fourth, because this study was limited to 2015-2016, this may limit the generalizability of the findings. Longitudinal research is needed to include years of study to gain a better understanding and results of the research problem.

\section{References}

Agyei-mensah, B. K. (2018). The Effect of Audit Committee Effectiveness and Audit Quality on Corporate Voluntary Disclosure Quality. African Journal of Economic and Management Studies. https://doi.org/10.1108/AJEMS-04-2018-0102

Akhtaruddin, M., \& Haron, H. (2010). Board Ownership , Audit Committees Effectiveness and Corporate Voluntary Disclosures. Asian Review of Accounting, 18(1), 68-82. https://doi.org/10.1108/13217341011046015

Al-shammari, B. (2013). An Investigation of Voluntary Disclosure by Kuwaiti Shariah -Compliant Companies. Journal of Economic and Administrative Sciences, 29(1), 21-41. 
https://doi.org/10.1108/10264111311319213

Allegrini, M., \& Greco, G. (2011). Corporate boards , audit committees and voluntary disclosure $\square$ : evidence from Italian Listed Companies. Journal Management Governance, 17, 187-216. https://doi.org/10.1007/s10997-011-9168-3

Bapepam. 2012. "Keputusan Bapepam No. KEP-431/BL/2012 tentang Penyampaian Laporan Tahunan Emiten atau Perusahaan Publik." https://www.ojk.go.id/id/regulasi/pages/BAPEPAM-XK6-tentang-PenyampaianLaporan-Tahunan-Emiten-atau-Perusahaan-Publik.aspx

Barako, D. G. (2007). Determinants of voluntary disclosures in Kenyan companies annual reports. Determinants of Voluntary Disclosures in Kenyan Companies Annual Reports, 1(August), 113-128. https://doi.org/10.5897/AJBM.9000203

Barako, D. G., Hancock, P., \& Izan, H. Y. (2006). Factors influencing voluntary corporate disclosure by Kenyan companies. Corporate Governance: An International Review, 14(2), $107-$ 125. https://doi.org/10.1111/j.1467-8683.2006.00491.x

Chen, C. J. P., \& Jaggi, B. (2000). Association between independent non-executive directors, family control and financial disclosures in Hong Kong. Journal of Accounting and Public Policy, 19(45), 285-310. https://doi.org/10.1016/S0278-4254(00)00015-6

Fatmawati, R., Astuti, D. W., \& Suhardjanto, D. (2018). Peran Corporate Governance dalam Meningkatkan Voluntary Disclosure. Jurnal Akuntansi Multiparadigma, 9(1), 57-69. https://doi.org/10.18202/jamal.2018.04.9004

Haddad, A. E., AlShattarat, W. K., AbuGhazaleh, N. M., \& Nobanee, H. (2015). The Impact of Ownership Structure and Family Board Domination on Voluntary Disclosure For Jordanian Listed Companies. In Eurasian Business Review (Vol. 5, Issue 2). Springer International Publishing. https://doi.org/10.1007/s40821-015-0021-5

Haniffa, R. M., \& Cooke, T. E. (2002). Culture, corporate governance and disclosure in Malaysian corporations. Abacus, 38(3), 317-349. https://doi.org/10.1111/1467-6281.00112

Harventy, G. (2020). The Role of Corporate Governance Improving Voluntary Disclosure. Jurnal Reviu Akuntansi Dan Keuangan, 10(3), 602-613. https://doi.org/10.1093/nq/s1-ix.228.217a

Ho, S. S. M., \& Shun Wong, K. (2001). A study of the relationship between corporate governance structures and the extent of voluntary disclosure. Journal of International Accounting, Auditing and Taxation, 10(2), 139-156. https://doi.org/10.1016/S1061-9518(01)00041-6

Ikatan Akuntan Indonesia. (2012). Standar Akuntansi Keuangan Per 1 Juni 2012 (1st ed.).

Jaffar, R., Mardinah, D., \& Ahmad, A. (2013). Corporate Governance and Voluntary Disclosure practices: Evidence From a Two Tier Board Systems in Indonesia. Jurnal Pengurusan, 39(2013), 83-92. https://doi.org/10.17576/pengurusan-2013-39-08

Krismiaji, K. (2020). Boards' Characteristics, Voluntary Disclosure, and Accounting Information Value Relevance - Indonesian Evidence. Jurnal Akuntansi Dan Bisnis, 19(2), 240. https://doi.org/10.20961/jab.v19i2.477

Milad, I. A. A., \& Bicer, A. A. (2020). The Association Between Board of Directors Characteristics and the Level of Voluntary Disclosure: Evidence from Listed Banks in Borsa Istanbul. Management \& Economics Research Journal, 2(1), 166-185. https://doi.org/10.48100/merj.v2i1.81

Nasih, M., Harymawan, I., Paramitasari, Y. I., \& Handayani, A. (2019). Carbon Emissions, Firm Size, and Corporate Governance Structure: Evidence From the Mining and Agricultural $\begin{array}{llll}\text { Industries in } \quad \text { Indonesia. } & \text { Sustainability (9witzerland), }\end{array}$ 
https://doi.org/10.3390/su11092483

Nugraheni, P., \& Anuar, H. A. (2014). Implications of Shariah on The Voluntary Disclosure of Indonesian Listed Companies. Journal of Financial Reporting and Accounting, 12(1), 76-98. https://doi.org/10.1108/JFRA-11-2011-0018

Otoritas Jasa Keuangan. 2014. "Peraturan Otoritas Jasa Keuangan No. 33/ POJK.04/ 2014 tentang Direksi dan Dewan Komisaris Emiten atau Perusahaan Publik." http://www.ojk.go.id/en/kanal/pasar-modal/regulasi/peraturan-ojk/Pages/OJK-

Regulation-Concerning-The-Board-of-Directors-and-The-Board-of-Commissioners-ofIssuers-of-Public-Companies.aspx

Pemerintah Republik Indonesia. 2017. "Peraturan Menteri Keuangan Republik Indonesia No. 88/ PMK.06/ 2015 tentang Penerapan Tata Kelola Perusahaan Yang Baik Pada Perusahaan Perseroan (Persero) Di Bawah Pembinaan Dan Pengawasan Menteri Keuangan." https://www.djkn.kemenkeu.go.id/2013/peraturan/detail/pmk-nomor-88pmk062015

Pernamasari, R. (2018). Implementation of Good Corporate Governance and Voluntary Disclosure Compliance: 100 Compass Index Companies Listed Indonesian Stock Exchange (IDX) 2015-2016. International Journal of Academic Research in Accounting, Finance and Management Sciences, 8(2), 235-249. https://doi.org/10.6007/ijarafms/v8-i2/4316

PricewaterhouseCoopers. (2014). Survey Bisnis Keluarga 2014. http://www.pwc.com/id/en/publications/assets/indonesia-report-family-businesssurvey-2014.pdf

Qu, W., Leung, P., \& Cooper, B. (2013). A Study of Voluntary Disclosure of Listed Chinese Firms - a Stakeholder Perspective. Managerial Auditing Journal, 28(3), 261-294. https://doi.org/10.1108/02686901311304376

Ratnasari, U., \& Adhariani, D. (2019). Family-owned and State-owned Firms Disclosure: Comparative Analysis of Indonesia Public Firms. Advances in Economics, Business and Management Research, 101(30), 50-53. https://doi.org/10.2991/iconies-18.2019.9

Rouf, A. (2011). Corporate characteristics, governance attributes and the extent of voluntary disclosure in Bangladesh. African Journal of Business Management, 5(19), 7836-7845. https://doi.org/10.5897/ajbm10.1180

Shehata, N. F. (2014). Theories and Determinants of Voluntary Disclosure. Accounting and Finance Research, 3(1), 18-26. https://doi.org/10.5430/afr.v3n1p18

Surya, I., \& Yustiavandana, I. (2006). Penerapan Good Corporate Governance $\square$ : Mengesampingkan Hak Istimewa Demi Kelangsungan Usaha (1st ed.). Kencana Prenada Media Group.

Suwardjono, S. (2011). Teori Akuntansi Perekayasaan Pelaporan Keuangan (3rd ed.). BPFE Yogyakarta.

Syahierah, R., \& Larasati, A. (2019). Does Company Size and Profitability Affect Corporate Social Responsibility Disclosure? Asian Journal of Islamic Management (AJIM), 1(1), 38-50. https://doi.org/10.20885/ajim.vol1.iss1.art4 